J. Amer. Soc. Hort. Sci. 115(5):854-857. 1990.

\title{
Inheritance and Assessment of Bentazon Herbicide Tolerance in 'Santaka' Pepper
}

\author{
Richard L. Fery ${ }^{1}$ and Howard F. Harrison, Jr. \\ U.S. Vegetable Laboratory, Agricultural Research Service, U.S. Department of Agriculture, 2875 \\ Savannah Highway, Charleston, SC 29414 \\ Additional index words. Capsicum annuum, herbicide resistance, vegetable breeding
}

\begin{abstract}
Experiments were developed to study the inheritance of the high level of tolerance to the herbicide bentazon exhibited by the pepper (Capsicum annuum $L_{\text {.) }}$ cultivar Santaka. Parental, $F_{1}, F_{2}$, and backcross populations of the cross 'Santaka' $x$ 'Keystone Resistant Giant' were evaluated for injury in a greenhouse test using bentazon at a rate of $4.5 \mathrm{~kg} \cdot \mathrm{ha}^{-1}\left(1.1 \mathrm{~kg} \times \mathrm{ha}^{-1}\right.$ is the rate recommended for most applications). Additionally, parental and $F_{1}$ populations were evaluated for injury under field conditions using sequential bentazon applications of 4.5, 4.5, 6.75, and 9.0 $\mathbf{k g} \cdot \mathrm{ha}^{-1}$. A single, dominant gene determined tolerance. $F_{1}$ hybrid plants (heterozygous at the locus conditioning tolerance) exhibited a high level of tolerance under field conditions. Results of the greenhouse test suggested a possible cytoplasmic involvement in the expression of the tolerance gene, but the results of the field test provided strong evidence that cytoplasm does not play a significant role. We propose that this gene be designated Bentazon tolerance and symbolized Bzt. Chemical name used: 3-(1-methylethyl)-(1H)-2,1,3-benzothiadiazin-4(3H)-one 2,2-dioxide (bentazon).
\end{abstract}

Bentazon is a selective postemergence herbicide used to control certain broadleaf weeds and sedges in various major agronomic crops. Although highly toxic to many pepper cultivars and not currently registered for general use on the crop, bentazon is of interest to the pepper industry because it controls several broadleaf weeds and sedges [particularly yellow nutsedge (Cyperus esculentus L.)] that cannot be controlled by currently registered herbicides. Additionally, most of the herbicides presently used by pepper growers are applied preplant and there is a need for an effective herbicide to control emerged broadleaf weeds and sedges in the later growth stages of the crop.

Faulkner (1982) noted that developing a cultivar tolerant to an existing herbicide known to kill problem weed species of a crop should be more economical than developing a new selective -herbicide; he estimated that the cost of developing a new cultivar is only $1 \%$ to $5 \%$ of the cost of developing a new herbicide. Development of tolerant cultivars may be the only feasible means to obtain new herbicides for some crops. Machado et al. (1982) pointed out that the extremely high costs of developing new herbicides is particularly relevant to horticultural crops because the profit potential is often insufficient to cover research and development costs.

Studies by Baltazar et al. (1984) and Harrison and Fery (1989) demonstrated that peppers exhibit a wide range of reactions to bentazon, and that the most tolerant accessions tolerated very high bentazon rates. Baltazar et al. (1984) reported that the $C$. chinense L. Cv. Bohemian Chili is highly tolerant. [We initially accepted Baltazar et al.'s (1984) characterization of this cultivar as $C$. chinense, but we now believe that it should be classified as $C$. апnиит.] Harrison and Fery (1989) discovered that high levels of bentazon tolerance are also available in C. аппиит germplasm; they reported that the C. annuит cv. Santaka exhibits a level of tolerance equal to that of 'Bohemian Chili'.

\footnotetext{
Received for publication 18 Sept. 1989. We acknowledge the assistance of N.L. Kelly, R.B. Cuthbert, H, and F.P. Maguire, agricultural research technicians. The cost of publishing this paper was defrayed in part by the payment of page charges. Under postal regulations, this paper therefore must be hereby marked advertisement solely to indicate this fact.

'Research Geneticist.

${ }^{2}$ Research Agronomist.
}

Except for the tabasco pepper (C. frutescent L.), virtually all commercial peppers grown in the United States are C. апnиum. 'Santaka' holds considerable promise for use as parental material in breeding bentazon-tolerant $C$. annuиm cultivars. The breeding value of any herbicide-tolerant germplasm would be enhanced greatly if the mode of inheritance were understood. Additionally, many modern pepper cultivars are hybrids and the utility of specific genes in development of such cultivars depends on the availability of detailed information about gene action under field conditions. These needs prompted us to study, under greenhouse and field conditions, the inheritance of the bentazon tolerance exhibited by 'Santaka'.

\section{Materials and Methods}

The data reported here are from greenhouse and field studies conducted at the U.S. Vegetable Laboratory, Charleston, S.C. Seeds of all parental, $\mathrm{F}_{1}, \mathrm{~F}_{2}$, and backcross generations of the cross 'Santaka' $\times$ 'Keystone Resistant Giant' were produced in the greenhouse using standard crossing and selfing procedures. The bentazon-tolerant 'Santaka' has a determinate growth habit and small, hot fruit borne in an erect position; the accession used in these studies was obtained in 1981 from the late A. Hugh Dempsey, Univ. of Georgia, Georgia Experiment Station, Experiment, Ga. 'Keystone Resistant Giant' is a popular bell pepper that is susceptible to bentazon injury. Except for the reciprocal of the $F_{1}$ cross, all plants selected for tests of the progeny populations contained 'Santaka' cytoplasm.

Greenhouse test. Seeds of the parental, $\mathrm{F}_{1}, \mathrm{~F}_{2}$, and backcross populations of the 'Santaka' $\times$ 'Keystone Resistant Giant' cross were germinated in vermiculite, and newly emerged seedlings were transplanted in 400-ml styrofoam pots containing a commercial sphagnum peat-vermiculite mix. The experimental design was a randomized complete block with four replications, each containing 310 single-plant plots. Each replicate contained 30 plants of each of the parents, 20 plants of each of the $F_{1}$ and reciprocal $F_{1}$ populations, and 70 plants of each backcross and $\mathrm{F}_{2}$ population. Ten plants of each population of each replicate were designated as untreated controls. All plants were fertilized weekly with a complete nutrient solution. The greenhouse was maintained between 24 and $32 \mathrm{C}$.

Bentazon was applied 25 days after transplanting at a rate of $4.5 \mathrm{~kg} \cdot \mathrm{ha}^{-1}$ with a laboratory sprayer that delivered a spray 


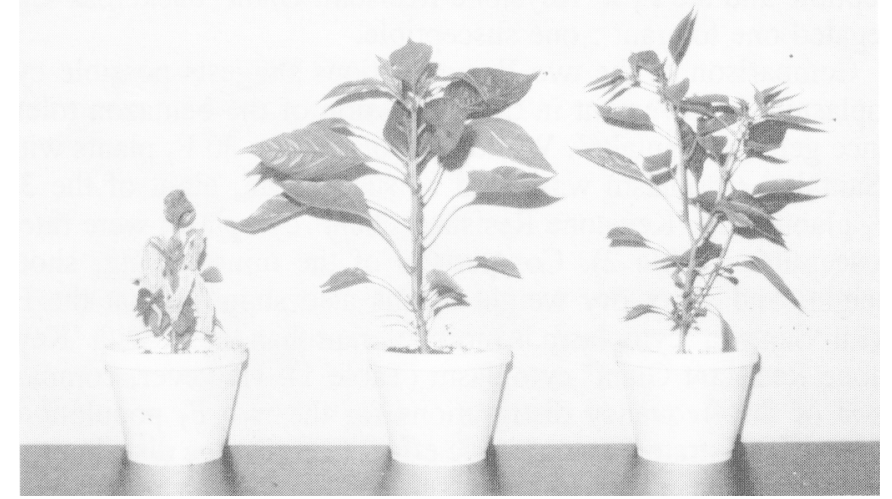

Fig. 1. Examples of effects of bentazon $\left(4.5 \mathrm{~kg} \cdot \mathrm{ha}^{-1} ; 2\right.$ weeks after application) on greenhouse-grown plants of the susceptible 'Keystone Resistant Giant' (left), the tolerant 'Santaka' (right), and the tolerant $F_{1}$ of 'Keystone Resistant Giant' x 'Santaka' (center). The leaves of the susceptible plant are severely damaged and only minimal damage is evident on the leaves of the tolerant plants

volume of 272 liters $\cdot \mathrm{ha}^{-1}$; a crop oil concentrate was included at $0.5 \%$ of the spray volume. At 1 and 2 weeks after treatment, each plant was visually rated for herbicide injury (injury rating) on a scale of 0 to $10(0=$ no injury, $3=$ moderate foliar chlorosis with small necrotic lesions, $7=$ severe necrosis, and $10=$ dead plant). Immediately after the second rating, each plant was clipped at the soil surface, the shoot height was recorded, and the shoots were placed in a forced-air drier. Shoot height and shoot dry weight were expressed as a percentage of control means.

The injury rating was used to classify each plant as either susceptible or tolerant to bentazon. All plants with a herbicide injury rating of 0 to 4 were classified as bentazon tolerant; plants rated 5 through 10 were classified as susceptible. Chi-square tests for goodness-of-fit were used in testing all genetic hypotheses.

Field test. The parental and reciprocal $\mathrm{F}_{1}$ populations of the 'Santaka' $\times$ 'Keystone Resistant Giant' cross were seeded in the greenhouse on 28 Mar. and the plants were transplanted to the field on 10 May. The experimental design was a randomized complete block with four replications, each containing 12 plots. Each replicate contained four plots of each of the parental populations and two plots of each of the reciprocal $F_{1}$ populations.
Two of the four parental population plots in each replicate were designated as untreated controls. Each plot consisted of a single row of 10 plants spaced $76 \mathrm{~cm}$ apart on beds $1 \mathrm{~m}$ apart.

Each treated plot received four bentazon applications. The herbicide was applied with a tractor-mounted sprayer as follows (in $\mathrm{kg} \cdot \mathrm{ha}^{-1}$ ): 16 June, 4.5 ; 30 June, 4.5; 11 July, 6.75; and 27 July, 9.0. The sprayer delivered a spray volume of 187 liters.ha ${ }^{-1}$; a crop oil concentrate was included at $0.0125 \%$ of the spray volume. Each plant was rated on 23 June, 5 and 15 July, and 2 Aug. using the herbicide injury scale (0-10) described above.

\section{Results and Discussion}

General. The procedures used to evaluate pepper plants for tolerance to bentazon were rapid and reliable. The major lesson learned was that care needs to be exercised to select uniformsized plants for testing; poorly developed or weak seedlings of tolerant lines can be severely damaged, particularly under greenhouse conditions, by high dosages of bentazon and easily misclassified. Plant growth in one replicate of the greenhouse test was uneven, probably because of an error in fertilizer application. Because the three remaining undamaged replicates contained adequate population sizes for the type of analysis planned, the data from the damaged replicate were discarded. Analyses of the injury ratings of plants in the greenhouse test indicated that the responses at 1 and 2 weeks were similar. Consequently, only data for the first week are presented. Preliminary analyses revealed no significant differences between replicates for either the greenhouse test or the field test. As a result, replicates were combined for all analyses.

Greenhouse test. The reactions of the parent lines to the 4.5$\mathrm{kg}$ bentazon/ha treatment were as expected (Fig. 1). 'Keystone Resistant Giant' plants exhibited severe injury, a 28\% reduction in shoot height and a 54\% reduction in shoot weight (Table 1). 'Santaka' plants exhibited a high level of tolerance, but they were not immune; the leaves exhibited slight to moderate injury, shoot height was reduced $8.7 \%$, and shoot dry weight was reduced $17 \%$. Comparison of the relative values of the injury rating, shoot height, and shoot dry weight means of the parental and progeny populations indicates that bentazon tolerance is inherited as a dominant trait. The comparative frequency distributions of reactions (injury ratings) of the plants in these populations to bentazon also indicate that the trait is inherited in a dominant manner (Fig. 2).

Segregation for bentazon tolerance in the progeny generations indicates that the bentazon tolerance in 'Santaka' is conditioned by a single dominant gene (Table 2). All but one of the $30 \mathrm{~F}_{1}$

Table 1. Injury rating, shoot height, and shoot dry weight of bentazon-treated plants of the parental, $\mathrm{F}_{1}, \mathrm{~F}_{2}$, and backcross populations of the cross 'Santaka' $\times$ 'Keystone Resistant Giant' (greenhouse test).

\begin{tabular}{lcccc}
\hline \hline & $\begin{array}{c}\text { No. } \\
\text { plants }\end{array}$ & $\begin{array}{c}\text { Injury } \\
\text { rating }^{z}\end{array}$ & $\begin{array}{c}\text { Shoot ht } \\
(\% \text { control })\end{array}$ & $\begin{array}{c}\text { Shoot } \\
\text { dry wt } \\
\text { (\% control) }\end{array}$ \\
\hline Santaka (S) & 60 & $2.00 \pm 0.11^{y}$ & $91.3 \pm 1.3$ & $82.9 \pm 2.5$ \\
Keystone Resistant Giant $(\mathrm{K})$ & 60 & $7.25 \pm 0.22$ & $72.4 \pm 2.6$ & $46.0 \pm 3.7$ \\
$\mathrm{~F}_{1}(\mathrm{~S} \times \mathrm{K})$ & 30 & $2.93 \pm 0.16$ & $85.6 \pm 2.0$ & $80.8 \pm 3.8$ \\
$\mathrm{~F}_{1}(\mathrm{~K} \times \mathrm{S})$ & 30 & $3.83 \pm 0.34$ & $81.3 \pm 2.7$ & $70.7 \pm 4.7$ \\
$\mathrm{~F}_{2}(\mathrm{~S} \times \mathrm{K})$ & 179 & $3.55 \pm 0.12$ & $80.6 \pm 1.1$ & $67.4 \pm 1.7$ \\
$\mathrm{BC}-\mathrm{S}\left[\mathrm{S} \times \mathrm{F}_{1}(\mathrm{~S} \times \mathrm{K})\right]$ & 180 & $2.54 \pm 0.06$ & $88.9 \pm 1.0$ & $81.2 \pm 1.2$ \\
$\mathrm{BC}-\mathrm{K}\left[\mathrm{F}_{1}(\mathrm{~S} \times \mathrm{K}) \times \mathrm{K}\right]$ & 179 & $4.89 \pm 0.16$ & $76.6 \pm 1.3$ & $57.5 \pm 1.9$ \\
\hline
\end{tabular}

${ }^{z}$ Mean $\pm S E$.

${ }^{y}$ Each plant rated on a scale of 0 to $10 ; 0=$ no obvious injury and $10=$ dead plant. 


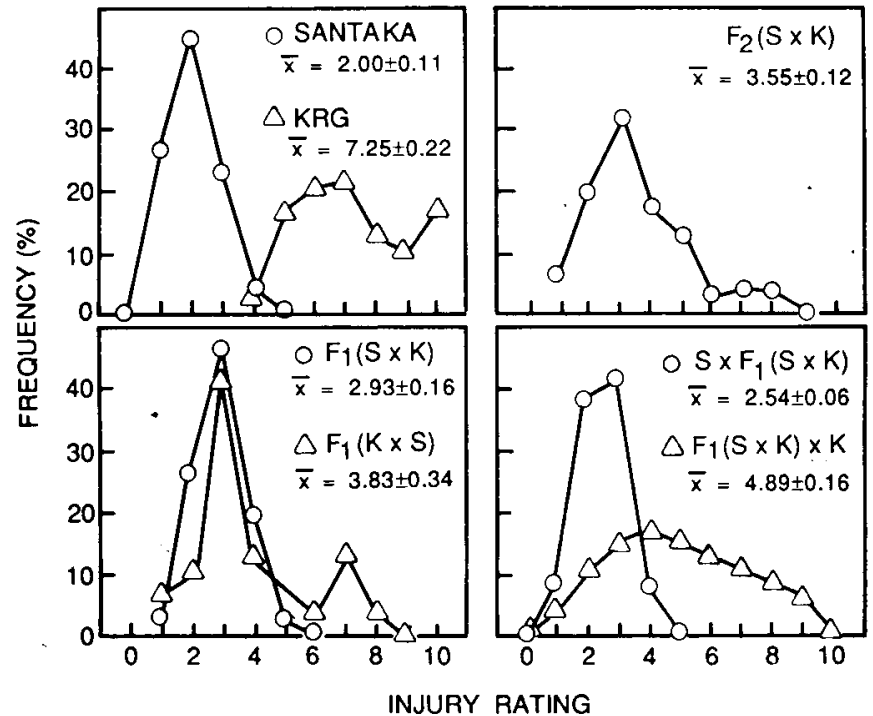

Fig. 2. Comparative frequency distributions of reactions $(\mathrm{O}=$ no injury; $10=$ dead plant) of greenhouse-grown plants from the parental, $\mathrm{F}_{1}, \mathrm{~F}_{2}$, and backcross populations of the cross 'Santaka' $\times$ 'Keystone Resistant Giant' to a 'single 4.5-kg.ha' application of bentazon.
('Santaka' X 'Keystone Resistant Giant') plants and all but three of the $180 \mathrm{~F}_{1} \times$ 'Santaka' backcross plants were of the expected tolerant phenotype. The $\mathrm{F}_{2}$ segregated three tolerant : one susceptible and the $F_{1} \times$ 'Keystone Resistant Giant' backcross segregated one tolerant : one susceptible.

Comparison of the two $F_{1}$ populations suggests possible cytoplasmic involvement in the expression of the bentazon tolerance gene in 'Santaka'. While only one of the $30 \mathrm{~F}_{1}$ plants with 'Santaka' cytoplasm was rated as susceptible, eight of the 30 $\mathrm{F}_{1}$ plants with 'Keystone Resistant Giant' cytoplasm were rated susceptible (Table 2). Comparison of the injury rating, shoot height, and shoot dry weight means also suggests that the F, with 'Santaka' cytoplasm is more tolerant than the $F_{1}$ with 'Keystone Resistant Giant' cytoplasm (Table 1). However, comparison of the frequency distributions for the two $\mathrm{F}_{1}$ populations does not illustrate a cytoplasmic effect (Fig. 2); the distributions of the tolerant plants (toxicity score $\leq 4$ ) in both populations are similar. A likely explanation for the unexpected "bimodal" distribution observed in the $F_{1}$ ('Keystone Resistant Giant $x$ 'Santaka') population is that we, did not select uniform plants for testing and that genetically tolerant but weak plants were injured by the bentazon treatment and subsequently misclassified.

Field test. The results of this test demonstrate clearly that 'Santaka' is highly tolerant to bentazon under field conditions (Fig. 3). Not only did this cultivar not suffer any serious injury

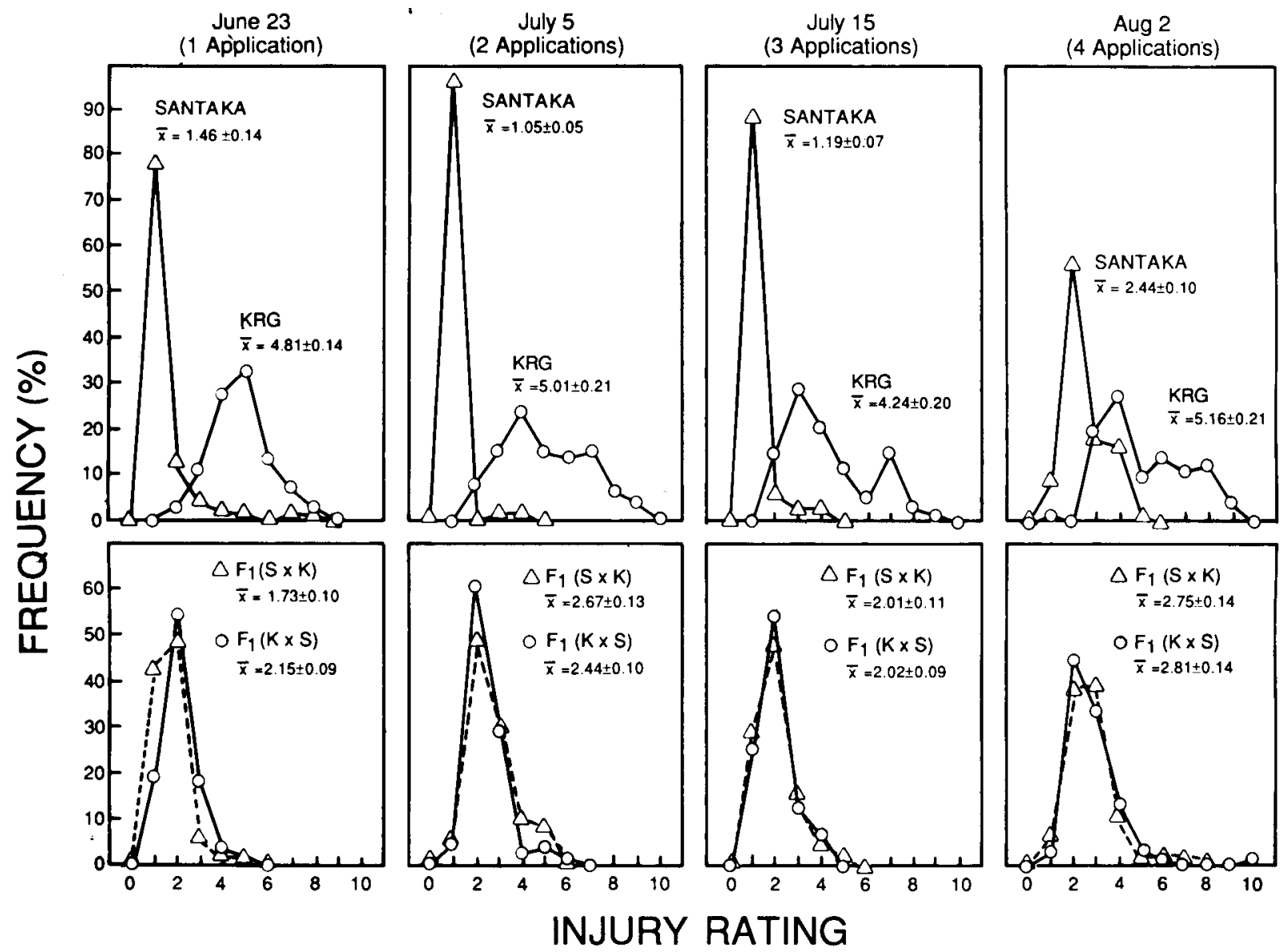

Fig. 3. Comparative frequency distributions of reactions of field-m-own plants from the parental and $F_{1}$ populations of the cross 'Santaka' $x$ 'Keystone Resistant Giant' to sequential applications of bentazon (4.5, 4.5, 6.75, and $9.0 \mathrm{~kg} \cdot \mathrm{ha} \mathrm{a}^{-1}$ applied on 16 and $30 \mathrm{June}$, and 11 and 27 July, respectively). Injury ratings $(\mathrm{O}=$ no injury; $10=$ dead plant) were taken after each application (23 June, 5 and 15 July, and 2 Aug.). 
Table 2. Segregation for bentazon tolerance in parental, $\mathrm{F}_{1}, \mathrm{~F}_{2}$, and backcross populations of the cross 'Santaka' $x$ 'Keystone Resistant Giant' (greenhouse test).

\begin{tabular}{|c|c|c|c|c|c|}
\hline \multirow[b]{2}{*}{ Test population } & \multicolumn{2}{|c|}{ No. plants in classes } & \multirow{2}{*}{$\begin{array}{c}\text { Expected } \\
\text { ratios } \\
(\mathrm{T}: S)^{\mathbf{x}}\end{array}$} & \multirow{2}{*}{$\begin{array}{c}\text { Chi } \\
\text { square }\end{array}$} & \multirow[b]{2}{*}{ Probability } \\
\hline & Tolerant ${ }^{z}$ & Susceptible & & & \\
\hline Santaka (S) & $60^{\circ}$ & 0 & All $\mathrm{T}$ & -- & $\ldots$ \\
\hline Keystone Resistant Giant (K) & 1 & 59 & All $S$ & -- & -.- \\
\hline$F_{1}(S \times K)$ & 29 & 1 & All $\mathrm{T}$ &.- & --- \\
\hline $\mathrm{F}_{1}(\mathrm{~K} \times \mathrm{S})$ & 22 & 8 & All $\mathrm{T}$ & $-\cdots$ & --- \\
\hline $\mathrm{F}_{2}(\mathrm{~S} \times \mathrm{K})$ & 136 & 43 & $3: 1$ & 0.09 & 0.76 \\
\hline $\mathrm{BC}-\mathrm{S}\left[\mathrm{S} \times \mathrm{F}_{1}(\mathrm{~S} \times \mathrm{K})\right]$ & 177 & 3 & All $\mathrm{T}$ & $-\cdots$ & $\ldots$ \\
\hline $\mathrm{BC}-\mathrm{K}\left[\mathrm{F}_{1} \cdot(\mathrm{S} \times \mathrm{K}) \times \mathrm{K}\right]$ & 84 & 95 & $1: 1$ & 0.68 & 0.41 \\
\hline
\end{tabular}

${ }^{x}$ Injury rating $\leqslant 4$.

YInjury rating $\geqslant 5$.

${ }^{\mathrm{T}} \mathrm{T}=$ tolerant; $\mathrm{S}=$ susceptible.

as a result of the initial $4.5-\mathrm{kg} \cdot \mathrm{ha}^{-1}$ application (four times the rate recommended for most applications), but it did not sustain serious injury as a result of additional sequential applications of 4.5, 6.75, and $9.0 \mathrm{~kg} \cdot \mathrm{ha}^{-1}$ The susceptible 'Keystone Resistant Giant' suffered severe injury in all instances.

Both of the $F_{1}$ hybrid populations exhibited a high level of tolerance to each of the four sequential bentazon applications. This observation indicates that the heterozygous condition at the locus for the gene conditioning bentazon tolerance is sufficient to condition a high level of tolerance. Thus, the production of bentazon-tolerant hybrid pepper cultivars should be a readily achievable plant breeding objective. This goal should be quickly achieved by using a backdross breeding procedure to incorporate the dominant bentazon tolerance gene into just one of the inbred parental lines.

The frequency distributions of reactions of field-grown plants from the $F_{1}$ hybrid populations to sequential applications of bentazon provide strong evidence that cytoplasm does not play a significant role in the expression of the bentazon tolerance gene (Fig. 3). The frequency distributions for the $F_{1}$ population with 'Santaka' cytoplasm are similar to the distributions for the

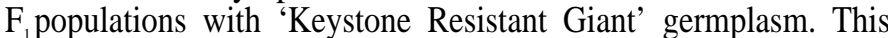
finding means that plant breeders and hydrid seed producers can use bentazon-tolerant breeding lines as either seed or pollen parents without fear of losing some of the tolerance.

\section{Conclusions}

The results of the present study indicate that a single, dominant gene conditions the high level of tolerance in the pepper cultivar Santaka to the herbicide bentazon. We propose that this gene be designated Bentazon tolerance and symbolized Bzt. The ease and reliability of evaluating plants for bentazon tolerance and the availability of a simply inherited source of tolerance makes bentazon tolerance a viable objective in pepper breeding programs. The objective should be readily obtainable by the application of classical genetics and plant breeding methodologies.

\section{Literature Cited}

Baltazar, A. M., T.J. Monaco, and D.M. Peele. 1984. Bentazon selectivity in hot pepper (Capsicum chinense) and sweet pepper (Capsicum аппиит). Weed Sci. 32:243-246.

Faulkner, J.S. 1982. Breeding herbicide-tolerant crop cultivars by conventional methods, p. 235-256. In: H.M. LaBaron and J. Gressel (eds.). Herbicide resistance in plants. Wiley, New York.

Harrison, H. F., Jr., and R.L. Fery. 1989. Assessment of bentazon tolerance in pepper (Capsicum sp. ). Weed Tech. 3:307-312.

Machado, V. S., S.C. Phatak, and I.L. Nonnecke. 1982. Inheritance of tolerance of the tomato (Lycopersicon esculentum Mill. ) to metribuzin herbicide. Euphytica 31:129-138. 